REVISTA DE GEOMORFOLOGIE (2018) 20: 43-55

DOI 10.21094/rg.2018.017

www.geomorfologie.ro, http://revistadegeomorfologie.ro

\title{
Mid and Late Holocene evolution of Brateș Lake region (Danube floodplain) based on the multiproxy analysis
}

\author{
Laurențiu ȚUȚUIANU ${ }^{1}$, Alfred VESPREMEANU-STROE ${ }^{1,2^{*}}$, Florin PENDEA ${ }^{3}$, Tiberiu SAVA ${ }^{4}$ \\ ${ }^{1}$ GEODAR Research Center for Geomorphology, Geoarchaeology and Paleo-Environments, University of \\ Bucharest, 1 N. Bălcescu, 01004 Bucharest, Romania \\ ${ }^{2}$ Sfântu Gheorghe Marine \& Fluvial Research Station, Faculty of Geography, University of Bucharest, Sf. \\ Gheorghe, Tulcea, Romania \\ ${ }^{3}$ Lakehead University, Sustainability Sciences Department, 500 University Avenue, Orillia, ON L3V0B9, \\ Canada \\ ${ }^{4}$ RoAMS Laboratory, Horia Hulubei National Institute for R\&D in Physics and Nuclear Engineering, 30 \\ Reactorului, 077125 Măgurele, Romania
}

Received 2 December 2018; Revised 15 December 2018; Accepted 17 December 2018

*Correspondence to: Alfred VESPREMEANU-STROE, e-mail: fredi@geo.unibuc.ro

\begin{abstract}
This study proposes a local paleo-landscape reconstruction of the Danube floodplain based on a stratigraphic sequence retrieved from Brateș Lake which, by its emplacement near the confluence of Danube - Prut rivers, was fully receptive to changes associated to hydrological, geomorphological or anthropogenic driven events. Due to its intermediate position within the Lower Danube valley Brateș Lake is a proxy for the evolution of Cotul Dunării area (the region of Danube valley turning from $\mathrm{S}-\mathrm{N}$ to $\mathrm{W}-\mathrm{E}$ direction) and provide valuable information about the timing of Danube river advancement to the Black Sea after its reconnection to World Ocean. The sediments were analysed to get the history of their deposition by means of accelerator mass spectrometry (AMS) 14C dating, grain-size parameters, organic matter and carbonate content, magnetic susceptibility together with paleo-fauna and pollen content which altogether led to the identification of main stages: i) delta front advance into Danube estuary (before 8000 BP), ii) shoreline foreshore deposits which describe shoreline position (8000-7900 yrs BP), iii) river floodplain development (7900-5300/5000 yrs BP), iv) lake formation (5300/5000 yrs BP - present).
\end{abstract}

KEYWORDS

landscape changes, aggradation, chronology, stratigraphy units 


\section{Introduction}

The complex information and the highly diverse proxy elements archived within the preserved sediments render fluvial systems as one of the most intensively studied natural systems on the Earth surface. Since the middle of the 20th century, the number of studies looking for the answer of sedimentary fluvial systems to past environment changes grew considerably and were largely focused on three main issues: the influence of tectonic movements (Molnar and England, 1990; Merritts et al., 1994; Burbank and Pinter, 1999; RuszkiczayRudiger et al., 2016; Arzhannikova et al., 2018), imprints of the climate changes and of the sea level fluctuations (Probst, 1989; Pillans et al., 1998; Blum and Törnqvist, 2000) and the complex links with the human activities and settlements (Gebica et al., 2013; Wilkinson et al., 2014; Jotheri et al., 2016).

Most of the studies concern on a single major event, e.g. the Late Glacial - Holocene transition (Starkel et al., 2007; Turner et al., 2013), the fast sedimentation induced by human activities in the last millennium (Kalicki, 2000; Hoffmann et al., 2008; Kaplan et al., 2009; Morin et al., 2011), with an acceleration in the 19th century and the first half of the 20th century, followed by a sudden decrease as a result of dams constructions in the river basins (Owens et al., 1999; Panin and Jipa, 2002; Preoteasa et al., 2016; Stacke et al., 2014). Recently appeared new studies that treat the avulsions history on long periods of time during Holocene (Tigris and Euphrates: Morozova, 2005; Jotheri et al., 2016; Saskatchewan: Smith et al., 1989; Smith et al.,1998; Morozova and Smith, 1999; Mississippi: Aslan and Autin, 1999; Rhin: Törnqvist, 1994; van Dinter et al., 2017; Meuse: Stouthamer and Berendsen, 2001) or their types and morphodynamics: progradational, reoccupation and anthropic avulsions (Törnqvist and van Dijk, 1993; Morozova and Smith, 1999; Morozova, 2005).

In Romania there is a recent soar for the studies based on the chronostratigraphy of the fluvial archives, especially for the inner medium-size rivers (Teleorman: Howard et al., 2004; Someșul Mic and Transylvanian rivers: Perșoiu and Rădoane, 2011; Perșoiu et al., 2017; Siret: Rădoane et al., 2015, 2018, this volume), whereas those focusing on the Danube are mostly referring to the Danube Delta (Panin, 2003; Giosan et al., 2006, 2012; Vespremeanu-Stroe et al., 2013; Preoteasa et al., 2016, 2018; Vespremeanu-Stroe et al., 2016, 2017a, b) or to the Danube terraces (Armaș et al., 2018). Recently, a German team which developed a geoarchaeological study on the Neolithic site of Pietrele proposed a local and then regional valley paleogeography reconstruction for Pietrele and Giurgiu-Oltenița sectors (Nowacki and Wunderlich, 2012; Benecke et el., 2013; Nowacki et al., 2018).

The present study also aims to explain the combined impact of the sea level rise and human activities on the evolution of Danube Floodplain in the Brateş Lake area after the reconnection of Black Sea with Planetary Ocean as well as its level fluctuations which induced important fluctuations in the local level of the groundwater level. To prove this, a full stratigraphic sequence was retrieved from Brateș Lake which, by its emplacement within the Lower Danube valley and its position near the main fluvial channel (Fig. 1) was fully receptive to changes associated to hydrological, geomorphological or anthropogenic driven events. The sediments were analysed to obtain the general chronologic framework of their deposition by means of $14 \mathrm{C}$ dating, textural characteristics, palaeofaunistic load in order to get the general picture of the Mid and Late Holocene environmental changes.

\section{Methodology}

This study is based on a $8 \mathrm{~m}$ long core (Fig. 2) performed with an Eijkelkamp percussion corer system into the southern part of the Brateș Lake, which is drained today and used as arable land. In the present, Brateş Lake has a surface of ca. $20 \mathrm{~km} 2$, much smaller than at the beginning of 18th century (Cantemir, 1716), when it had around $100 \mathrm{~km} 2$. From the same historical source we found that the lake was fed with sediments from Prut during rainy seasons, through a small channel called Pruteţ, and from the Danube at large floods (Cantemir, 1716).

The sediment was sampled in $1 \mathrm{~m}$ long PVC pipes, each of them being labelled and sealed immediately after their retrieval and refrigerated at $4^{\circ} \mathrm{C}$. The pipes have been opened and described in the 
laboratory. Subsequently, 175 samples of sediment have been collected at ca. $20 \mathrm{~cm}$ equidistance and corresponding to each stratigraphy change for textural, loss on ignition (LOI), geochronology, magnetic susceptibility and micro-fauna analyses (for example between $425-500 \mathrm{~cm}$ were collected 9 samples for grain-size and LOI analyses and 1 sample for dating).

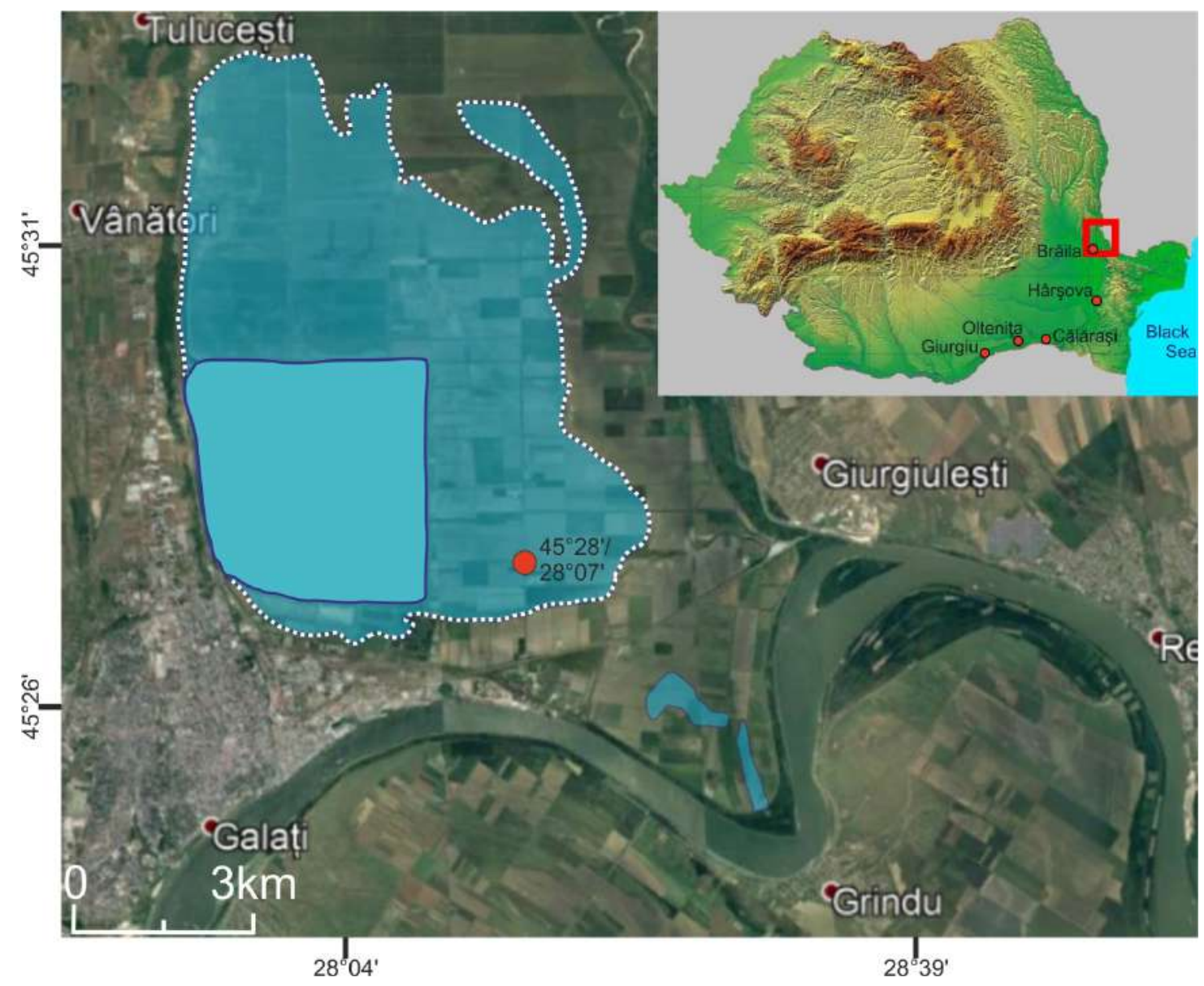

Figure 1 Present location and the former extent (1911; dotted white line) of Brateș Lake before partly desiccation (occurred in 1947-1949), overlapped on 2016 Google Earth image. The red circle marks the position of the core site. Inset: Position of the study site within the Lower Danube Valley / Romania

The chronostratigraphy of the cores was established on five independent AMS radiocarbon dates derived from vegetation fossils/remains, including one peat sample and one small piece of wood (Table 1). Radiocarbon dating measurements were undertaken at two different laboratories: three samples at Gliwice Radiocarbon Laboratory (Poland) and two at Horia Hulubei National Institute for R\&D in Physics and Nuclear Engineering (Romania) (Sava et al., 2018). $14 \mathrm{C}$ ages were subsequently calibrated using the OxCal online: (Ramsey, 1995), https://c14.arch.ox.ac.uk/oxcal/OxCal.html.

Grain-size analysis was realized on 78 samples which, before being measured with Horiba LA950
(Laser Diffraction Particle Size Analyzer), were attacked twice with $20 \%$ acetic acid $(\mathrm{CH} 3 \mathrm{COOH})$, washed twice with distilled water and then attacked for several times with $10 \%$ hydrogen peroxide $(\mathrm{H} 2 \mathrm{O} 2)$ to destroy the organic matter content. Then they were washed with distilled water 3 times. Before each reading, several milligrams of sodium polyphosphate were added to each sample to disperse the particles. The calculations on raw data were performed in the GRADISTATV8 program (Blott and Pye, 2001) using the equations developed by Folk and Ward (1957) for grain-size parameters such as mean, sorting, skewness and kurtosis. 
Loss on Ignition (LOI) is a cheap and quick method to calculate organic carbon or organic matter and inorganic carbon content. 75 samples, weighing between 2.72 and 4.13 grams, were dried at room temperature for 36 hours. The crucibles were dried at $150^{\circ} \mathrm{C}$ for 1.5 hours, then cooled and weighed. After that the sediment was added and burnt in three steps: at $105^{\circ} \mathrm{C}$ for 12 hours (to determine the water content); $550^{\circ} \mathrm{C}$ for 6 hours and $950^{\circ} \mathrm{C}$ for 2 hours in a Caloris L1003 oven. After each burning the samples were weighed with an accuracy of 0.0001 grams. To determine the amount of organic and inorganic carbon, the formulas developed by Heiri et al., (2001) were used.

Magnetic susceptibility (MS) was performed at 58 points with a Bartington 3MS device to determine the magnetic susceptibility of the different layers. In general, small susceptibility is associated with an increased content in organic matter (diamagnetic), while high values are associated with the terrigenous sediment flux (ferromagnetic) (Hatfield et al., 2013).

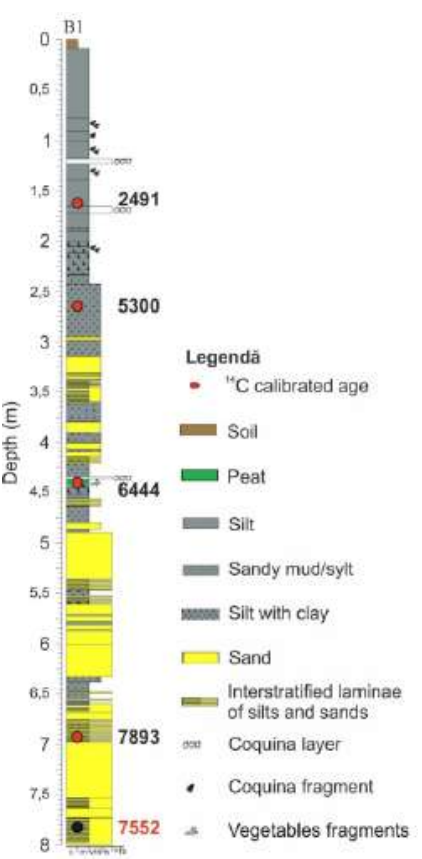

Figure 2 Stratigraphy and chronology of the core based on texture properties and calibrated radiocarbon dates. The deepest sample (Bra_69) was considered an outlier due to the very small size (below the standards)

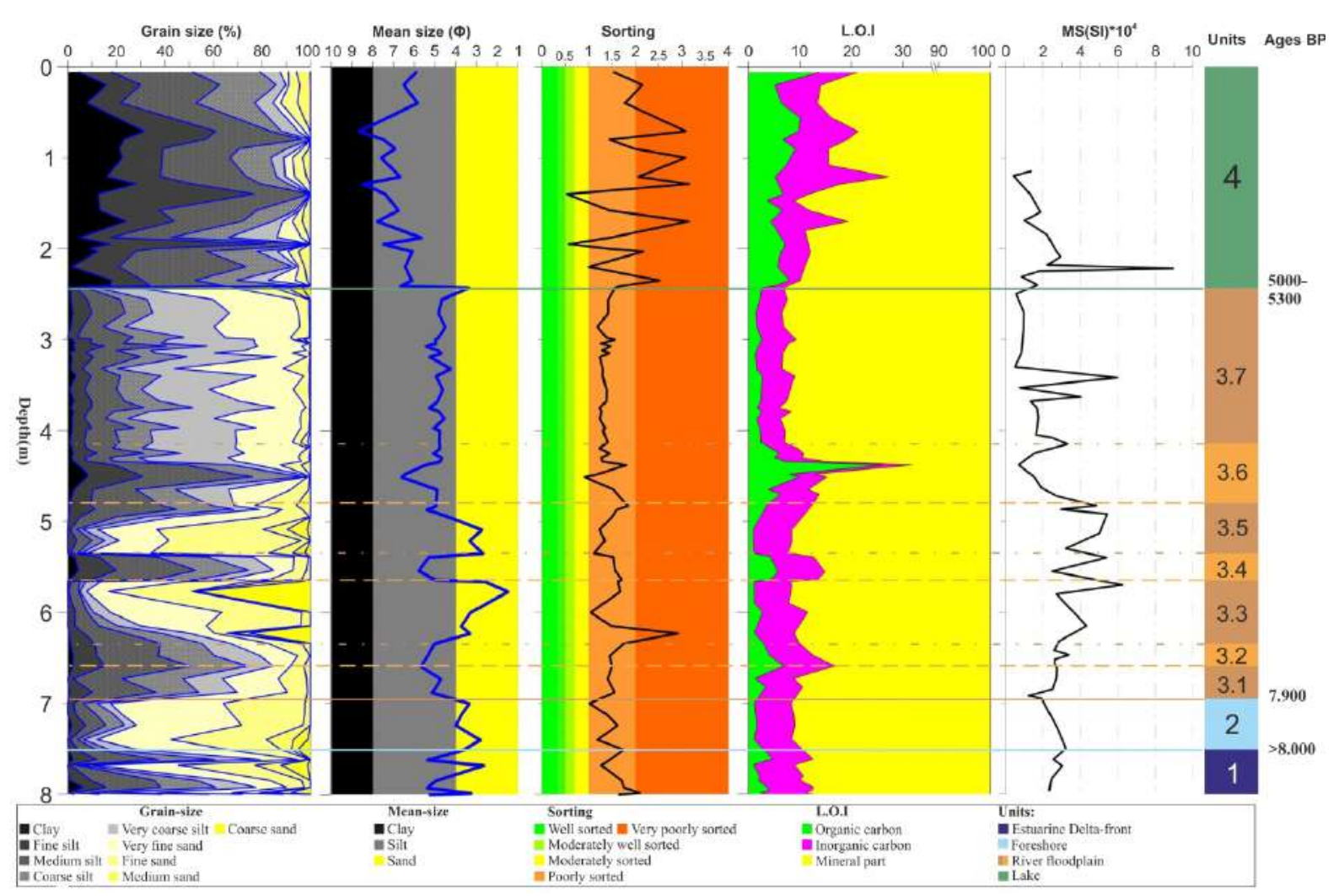

Figure 3 The physical and magnetic proprieties of the Brateș Lake sediment record: percentage of each grains-size class, mean grain-size, sorting, percentage of mineral and LOI (organic matter and carbonate content), mass specific magnetic susceptibility. The right coloured bar expresses the succession of different facies; all the ages are expresses in years BP 
Micro-fauna and pollen analyses were done at the Faculty of Geology in Bucharest and at Lakehead University from Canada, on more than ten samples.

Microfaunal analyses were carried out on samples from each sedimentological facies, to infer water paleosalinity and depositional environments. Samples were oven dried at $60^{\circ} \mathrm{C}$, weighed and then wet-sieved using tap water and sieves of $125 \mu \mathrm{m}$ and $63 \mu \mathrm{m}$. All valves belonging to ostracods and

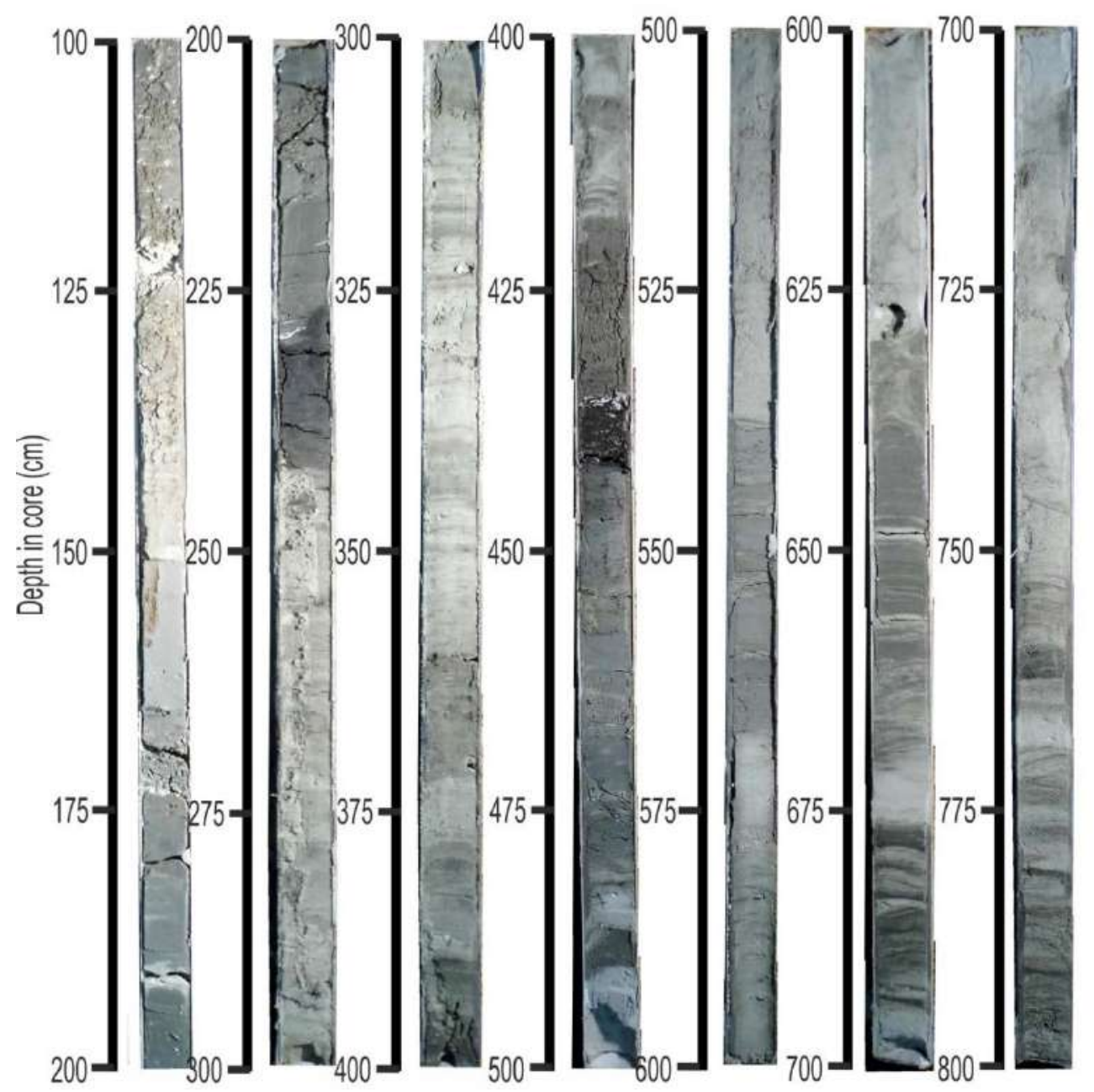

Figure 4 Photographic cores sequence shows the 1-8 meters stratigraphy

\section{Results}

A general stratigraphy based on visual logging, grain-size parameters (mean-size and sorting), LOI, micro-faunal and pollen analyses and magnetic susceptibility measurement is presented in Figure 3.

The core is mainly composed by poorly sorted muds and sands including vegetal remains and one thin peat layer (at $435-440 \mathrm{~cm}$ ) which could be dated. In the first two meters distinct layers with foraminifera were counted. Juvenile ostracods valves in the size fraction of $63-125 \mu \mathrm{m}$ were only observed to ensure that the population is paleoenvironmental reliable (in situ assemblage). Species identification and their paleoecological interpretation were done based on Opreanu (2004), Meisch (2000) (ostracods); Kaminski et al. (2002), Briceag and Ion (2014) (foraminifers). 
peat layers whilst Cinorg is associated with coquina, fish bones and different sediments which contain $\mathrm{CaCO}$. Magnetic susceptibility generally shows higher values in sandy units and smaller in silts. Regarding units, the highest average susceptibility is found in Unit $3\left(3.3 \mathrm{SI}^{\star} 104\right)$ and the smallest in Unit 4 $\left(2.3 \mathrm{SI}^{\star} 104\right)$, while in the first 2 units have an average of $2.6 \mathrm{SI}{ }^{\star} 104$.

All variations of those parameters, plus 13 samples which were analysed for micro-fauna or/and pollen content, describe the evolution model of the area divided into four stratigraphic units, in ascending order: 1 - a sandy unit with tens of layers of silts (Fig. 3,4 ) which was settled before $\sim 8500$ years $\mathrm{BP}, 2$ - homogeneous fine and very fine sand (until $\sim 7.900$ years BP), 3 - a matrix of mostly coarse silts and very fine sands which is composed from 7 layers with different thickness from which three of them are silty (3.1, 3.3, 3.5 and 3.7) and another three are sandy (3.2; 3.4 and 3.6) (until $~ 5000$ yrs BP), and unit 4 - which is composed by fine silts with a content of more than $15 \%$ clay (was present until the middle of the 20th century).

\subsection{Chronology}

The chronological framework is built on five ages obtained on three different type of material (Table 1). However, only four of them were used for agedepth model, because the sample from $782 \mathrm{~cm}$ is younger than the above sample $(692 \mathrm{~cm})$ and con- sidering the very small quantity of material which hampered the dating procedures we deemed it as outlier.

Regarding the age-depth model (Fig.5), this was obtained as a linear interpolation between dated levels with Clam in R-program (Rx64 3.5.1). The model shows high sedimentation rates before $5300 \pm 30 \mathrm{BP}(>1.5 \mathrm{~mm} / \mathrm{y})$, followed by a slow aggradation between $5300 \pm 30$ and $2491 \pm 130$ BP $(<0.35$ $\mathrm{mm} / \mathrm{y})$ with a slight increase after this date $(>0.65$ $\mathrm{mm} / \mathrm{y})$.

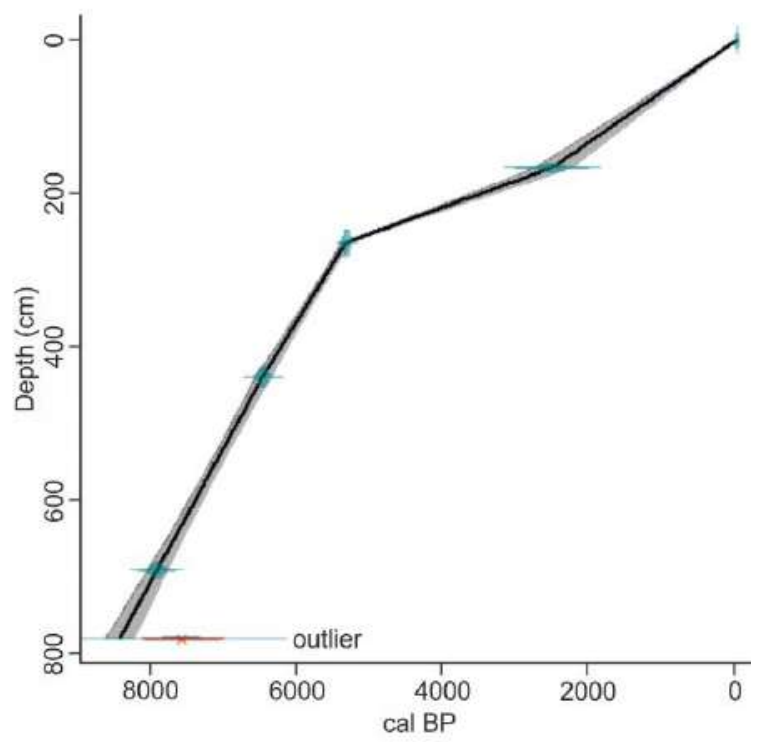

Figure 5 Age-depth model of the B1 core (obtained in R with Clam software)

Table 1 Summary of radiocarbon age results. AMS $14 \mathrm{C}$ dating was carried out by the GADAM Centre Gliwice Absolute Dating Methods Centre (marked with asterisk) and RoAMS Laboratory of the Horia Hulubei National Institute for R\&D in Physics and Nuclear Engineering. All absolute ages used in the paper were converted in calibrated years BP (with reference to 1950 AD)

\begin{tabular}{c|ccccc}
\hline Sample & Depth $(\mathbf{m})$ & Material & Coordinates (lat N/long E) & Conventional 14C age (years BP) & Cal. Age (BP) \\
\hline Bra_62 & 168 & Foliar & $45^{\circ} 28^{\prime} 00.7^{\prime \prime} / 28^{\circ} 07^{\prime} 25.1^{\prime \prime}$ & $2452 \pm 37$ & $2491 \pm 130$ \\
Bra_60* & 265 & Peat & $45^{\circ} 28^{\prime} 00.7^{\prime \prime} / 28^{\circ} 07^{\prime} 25.1^{\prime \prime}$ & $4590 \pm 35$ & $5300 \pm 30$ \\
Bra_65* & 440 & Foliar & $45^{\circ} 28^{\prime} 00.7^{\prime \prime} / 28^{\circ} 07^{\prime} 25.1^{\prime \prime}$ & $5650 \pm 30$ & $6444 \pm 52$ \\
Bra_68* & 692 & Wood & $45^{\circ} 28^{\prime} 00.7^{\prime \prime} / 28^{\circ} 07^{\prime} 25.1^{\prime \prime}$ & $7060 \pm 40$ & $7893 \pm 71$ \\
Bra_69 & 782 & Foliar & $45^{\circ} 28^{\prime} 00.7^{\prime \prime} / 28^{\circ} 07^{\prime} 25.1^{\prime \prime}$ & $6660 \pm 158$ & $7552 \pm 285$ \\
\hline
\end{tabular}




\subsection{Description of stratigraphic units}

Unit 1 is situated between 800 to 755 centimetres. The grain-size is composed by tens of layers of silt interbedded within a poorly sorted fine sandy matrix (Fig. 4). This unit has a small content of Corg ( 3\%) but a high content of Cinorg ( 8.4\%) and a medium magnetic susceptibility.

This is the only unit with the highest weight of marine dinoflagelatta species (Alexandrium pseudogonyaulax; Brigantedinium simplex; Petapharsodinium dalei; etc), salt water ostracodes (Euxinocythere sp.; Cytheromorpha fuscata and Euxinocythere iopatici) and foraminifera (Lagena vulgaris; Entolingulina deplanata) (Fig. 6). At the same time, there is a high content of degraded seeds and pollen grains besides many fragments of micro-fauna which cannot be identified. In terms of pollen, the Pinus and Poaceae species prevail against Picea, Betula and Tilia which are comparatively less represented (Fig. 7). Charcoal is also abundant.

Unit 2 fits 755 to $694 \mathrm{~cm}$ depth interval. The grain-size is composed of homogeneous fine sand, medium to poor sorted, yet better than that of Unit 1. This unit has a very small content of Corg ( 1.3\%) but significantly higher for Cinorg ( 7.3\%) whereas magnetic susceptibility maintains at similar levels as the adjacent units. The basal part of this unit is populated by a few specimens of foraminifera while the number of pollen granules increases for Betula, Ulmus and Picea species.

Unit 3 is the thickest unit (4.5 meters), extending from 694 to $242 \mathrm{~cm}$ depth. It has 7 distinct layers: four of them composed by sands and sandy silt (3.1; 3.3; 3.5; 3.7 in Fig.3) and the other three are made of silts $(3.2 ; 3.4 ; 3.6)$. The silty layers are generally better sorted than sandy layers while mean of Corg content is almost double in the finer sub-units $(4.8 \%$ vs. $2.7 \%$, but in the sub-unit 3.5 it reaches a maximum value of $26 \%$ ); mean of MS values measuring just $3.1 \mathrm{SI}^{\star} 104$ vs $3.7^{\star} 104$.

Ostracodes are present only in the basal part (subunits 3.1 and 3.2) and they are mostly freshwater specimens (there are also present some brackish specimens counting for $18 \%$ ); in the rest of the unit they are missing.

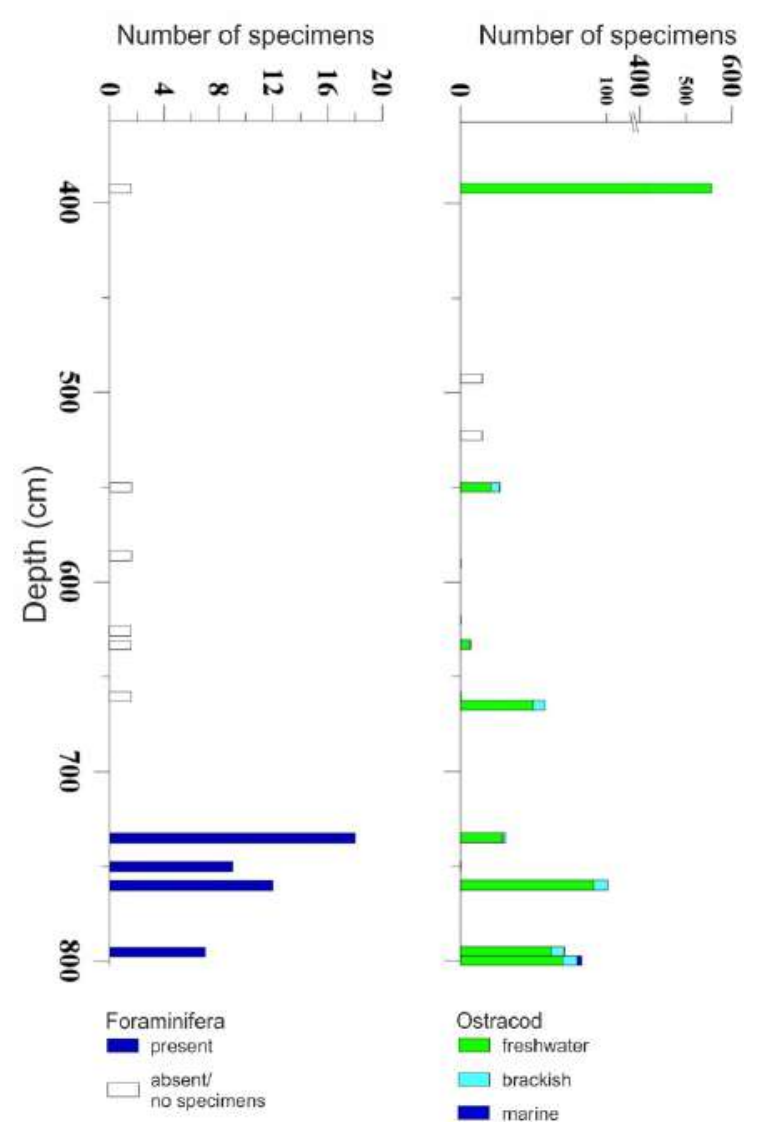

Figure 6 Ostracode and foraminifera assemblages

Unit 4 is located within the uppermost 242 centimetres, occupying the longest time period, due to a reduced sedimentation rate (Fig. 5). Grain-size is mostly fine silts and clay including few layers of mixed content (from medium sands to clay) which are very poor sorted. As an average, Unit 4 consists of more than $15 \%$ clay, $70-80 \%$ silt and approximately $5 \%$ sand, with a finer content in the middle. Corg content reaches the highest values ( 6.9\%) and Cinorg is slightly above average (7.8\%). Magnetic susceptibility has the smallest mean values from the entire core with several downs below $2 \mathrm{x}$ 104 , but also the main peak placed suddenly at 222 $\mathrm{cm}$ depth without any other transition. The degree of degradation for micro-fauna and pollen is very small compared to the basal part of the core. Grains of tree species, such as Pinus, Picea, Betula, Ulmus, have a decrease in percent, while others (Plopus and Quercus) have a slight increase or appear only here. The highest increase is among granules of the species Polypodiaceae (Fig. 7). 
ȚUȚIANU et al. / Revista de Geomorfologie 20 (2018)

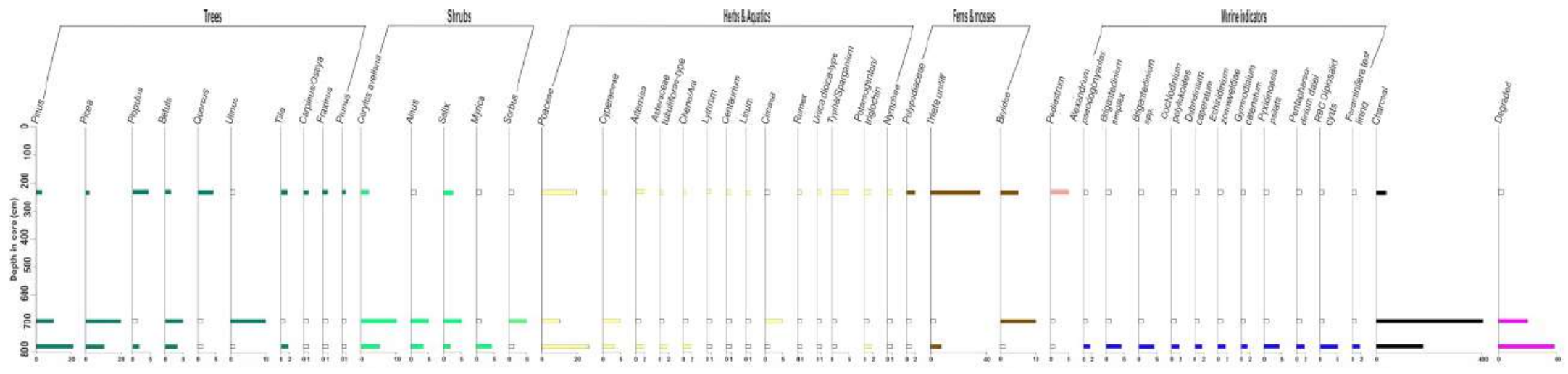

Figure 7 Pollen diagram and micro-fauna spectrum including marine indicators (white bars indicate the absence of specimens) 


\section{Discussions}

After the flooding of the Black Sea by the Mediterranean waters which occurred ca. 9200 BP (Soulet et al., 2011), the present day territory of the Danube delta and lower Danube floodplain was transformed into a shallow Danube Bay of varying widths constrained by the adjacent high relief. Taking into account the previous coring (Nowacki and Wunderlich, 2012; Benecke et al., 2013) performed upstream of Bălțile Dunării (which delimits the 15-25 km wide floodplain encompassed between the Danube arms between Călărași and Brăila) we assume that the Danube mouth was forced upstream by sea level rise as far as Giurgiu area, whilst in front of it an open-water lakescape developed (Nowacki et al., 2018).

During $9000-8000 \mathrm{BP}$ interval, despite of the sea level still rising at a high pace of ca. $2-4 \mathrm{~mm} / \mathrm{yr}$ (Lambeck and Purcell, 2005), Danube easily advanced downstream as documented by the modern delta plain building which started to form no later than 7500 BP (Vespremeanu-Stroe et al., 2017a, b). In this context, by its intermediate position within the Lower Danube Valley Brateș Lake is a proxy for the evolution of Cotul Dunării area (the region of Danube valley turning from $\mathrm{S}-\mathrm{N}$ to $\mathrm{W}-\mathrm{E}$ direction) and provide the first assessment of Danube river advance towards the Black Sea within the lower Danube floodplain. This study delivers valuable information about the timing of Danube river advancement into the Black Sea.

The sedimentologic and magnetometric analyses together with different microfauna and pollen determinations performed at several key-depths led to the identification of four main units which corresponds to major phases of landscape changes which affected the regional history of the (present) Brates Lake area during the mid- and late-Holocene.

\subsection{Estuarine delta front (Unit-1): before 8000 BP}

The stratigraphy of Unit 1 (Fig. 3, 4) is characterized by the alternation of fine (silts) lamina or thin layers and coarse sediments (sands) which is indicative for a delta front advance in the context of a large content of Cinorg and of a very high ratio between the Cinorg and Corg, which reach here the greatest values for the entire core, suggesting the influence of the marine environment (Wang et al., 2011). Foraminifera were found exclusively at depths bigger than $7.3 \mathrm{~m}$ whilst the ostracods assemblage contains a few marine species only in the lowermost sample, at $8 \mathrm{~m}$ depths, but more brackish species are present in this unit at different depths with the highest density even still low (12-16\%) (Fig. 6). Moreover, Unit-1 is the only one which contains different marine dinoflagelatta species (Fig. 7) but also a high content of degraded seeds and pollen grains besides many fragments of micro-fauna which cannot be identified due to energetic conditions of a brackish environment. All these proxies recommend Unit-1 as being part of a shoreface unit, respectively of the subaqueous Danube delta front advancing into an estuarine-like bay.

\subsection{Sandy foreshore / beach deposits (Unit-2): 8000 - 7900 BP}

The presence of massive and better sorted homogeneous sands (than in Unit-1) and of some foraminifera indicate swash sediment transport. On the other hand, the relatively small thickness of this deposit $(0.6 \mathrm{~m})$ and the modest sorting indicate a low-wave energy environment, yet still capable of building a thin sandy beach at the medium height of a fast advancing river delta shoreline. The age of $7893 \pm 71$ yrs BP (Table 1) measured on the limit between the Unit-2 and Unit-3 (Fig. 2) is the minimum age of the local (Danube) mobile coastline on its way to the Black Sea.

\subsection{River floodplain (Unit-3): 7900 - 5300/5000 BP}

Overlain on foreshore beach sands, the Unit-3 has a $4.5 \mathrm{~m}$ thick stratigraphy defined by the cyclic alternation of 7 main sub-units dominated either by medium-coarse (sands) or by fine (silts) sediments noted with odd, respectively even number in Figure 3. The sandy sub-units represent the rapid aggradation phases induced by secondary channel development (for the massive sandy layers), overbank and proximal crevasse-splay deposits (for the alternating structures) which are almost sterile for microfauna. 
The fine sub-units $(3.2,3.4,3.6)$ are the product of the interbedding of distal parts of crevassesplays and lacustrine sediments. They are always associated with LOI maxima (Fig. 3) and even if they are thinner than sandy sub-units, they become progressively thicker upcore $(25,30$ and $60 \mathrm{~cm})$ and represent the wet/submerged phases of the local floodplain when the site was covered by still shallow waters. The latest/uppermost sub-unit (3.6) is not only the largest fine sequence but it also includes the Corg main peak (at $440 \mathrm{~cm}$ depth) which corresponds to a peat layer covering the silty deposits which may be considered of lacustrine origin. The sandy sub-units represent the rapid aggradation phases induced by secondary channel development and overbank.

During this stage the mean sedimentation rate was of $1.6 \mathrm{~mm} / \mathrm{yr}$, respectively similar with that of the mean sea level rise $(1-2 \mathrm{~mm} / \mathrm{yr}$, which slowed down over time), which reveals a complex river floodplain evolution marked by successive stages of local submergence with swamps and shallow lake inception due to water level rise and rapid sandy aggradation phases during secondary channels development and associated crevasse-splays.

\subsection{Floodplain Lake (Unit-4): 5300/5000 - pre- sent}

River floodplain turned into a permanent lake around 5300-5000 BP, once with the relative stabilisation of the Holocene sea level and concomitant with the formation of the first Danube delta opencoast lobes (Giosan et al., 2006; Vespremeanu-Stroe et al., 2017a). In fact, between Unit-3 and Unit-4 is a sharp contact induced by a drop in the mean grainsize and a jump of clay content and LOI, especially for Corg (Fig. 3). Moreover, the lower 10-cm layer is a dark grey layer (Fig. 4) with high organic matter content indicating an episode of a marshy wetland which subsequently transformed into a shallow lake.

The sedimentation rate computed for this unit is of ca. $0.48 \mathrm{~mm} / \mathrm{yr}$ which is the minimum of the last 8000 years with the lowest rate of $0.35 \mathrm{~mm} / \mathrm{yr}$ during first stage of lake development (5300-2500 BP) but significantly higher $(0.65 \mathrm{~mm} / \mathrm{yr})$ since Antiquity to present in accordance with Danube sediment load increase due to man-induced vegetation changes in the watershed (Kaplan et al., 2009).

\section{Acknowledgements}

The authors are grateful to Dr. Luminița Preoteasa for her invaluable help in the field and for reviewing and substantial improving of this manuscript along with an anonymous reviewer, to Prof. Cristian Panaiotu and Dr. Sabin Rotaru for MS measurements and respectively for ostracoda and foraminifera identification and to our colleagues Liliana Croitoru and Răzvan Popescu who kindly accompanied us during the fieldwork. Goji is acknowledged for inspiring us and providing the joy of the hard work on the field. This work was supported by a grant of Ministry of Research and Innovation, CNCS - UEFISCDI, project number PNIII-P1-1.1-TE-2016-1750, within PNCDI III.

\section{References}

Armaş I, Necea D, Miclăuş C. 2018. Fluvial terrace formation and controls in the Lower River Danube, SE Romania. Quaternary International. https://doi.org/10.1016/j.quaint.2018.03.031.

Arzhannikova A, Arzhannikov S, Braucher $R$, Jolivet $M$, Aumaître G, Bourles D, Keddadouche K. 2018. Morphotectonic analysis and $10 \mathrm{Be}$ dating of the Kyngarga river terraces (southwestern flank of the Baikal rift system, South Siberia). Geomorphology 303: 94105.

Aslan A, Autin WJ. 1999. Evolution of the Holocene Mississippi River floodplain, Ferriday, Louisiana; insights on the origin of fine-grained floodplains. Journal of Sedimentary Research, 69(4): 800-815.

Benecke N, Hansen S, Nowacki D, Reingruber A, Ritchie K, Wunderlich J. 2013. Pietrele in the Lower Danube region: integrating archaeological, faunal and environmental investigations. Documenta Praehistorica, 40: 175-193.

Blott SJ, Pye K. 2001. GRADISTAT: a grain-size distribution and statistics package for the analysis of unconsolidated sediments. Earth Surface Processes and Landforms, 26(11): 1237-1248.

Blum MD, Törnqvist TE. 2000. Fluvial responses to climate and sea-level change: a review and look forward. Sedimentology, 47: 2-48.

Briceag A, Ion G. 2014. Holocene ostracod and foraminiferal assemblages of the Romanian Black Sea shelf. Quaternary International, 345: 119-129. 
Burbank DW, Pinter N. 1999. Landscape evolution: the interactions of tectonics and surface processes. Basin Research, 11(1): 1-6.

Cantemir D. 1716. Descriptio Moldaviae, republished in Romanian in 1973, Ed. Academiei, 267 p.

Folk RL, Ward WC. 1957. Brazos River bar: a study in the significance of grain-size parameters. Journal of Sedimentary Research, 27(1): 3-26.

Gębica P, Starkel L, Jacyšyn A, Krąpiec M. 2013. Medieval accumulation in the Upper Dniester river valley: The role of human impact and climate change in the Carpathian Foreland. Quaternary International, 293: 207218.

Giosan L, Donnelly JP, Constantinescu S,, Filip F, Ovejanu I, Vespremeanu-Stroe A, Vespremeanu E, Duller GAT. 2006. Young Danube delta documents stable Black Sea level since the middle Holocene: Morphodynamic, paleogeographic, and archaeological implications. Geology, 34(9): 757-760.

Giosan L, Coolen M, Kaplan JO, Constantinescu S, Filip F, Filipova-Marinova M, Kettner AJ, Thom N. 2012. Early anthropogenic transformation of the Danube Black Sea system. Scientific Reports, 2: 1-6.

Hatfield RG, Stoner JS, Jennings AE. 2013 December. Paleo- and environmental magnetic record of Holocene marine sediments from West Greenland. In: AGU Fall Meeting Abstracts.

Heiri O, Lotter AF, Lemcke G. 2001. Loss on ignition as a method for estimating organic and carbonate content in sediments: reproducibility and comparability of results. Journal of paleolimnology, 25(1): 101-110.

Hoffmann T, Lang A, Dikau R. 2008. Holocene river activity: analysing 14C-dated fluvial and colluvial sediments from Germany. Quaternary Science Reviews, 27(21-22): 2031-2040.

Howard AJ, Macklin MG, Bailey DW, Mills S, Andreescu R. 2004. Late-glacial and Holocene river development in the Teleorman Valley on the southern Romanian Plain. Journal of Quaternary Science, 19(3): 271-280.

Jotheri J, Allen MB, Wilkinson TJ. 2016. Holocene avulsions of the Euphrates River in the Najaf area of Western Mesopotamia: impacts on human settlement patterns. Geoarchaeology, 31(3): 175-193.

Kalicki T. 2000. Grain size of the overbank deposits as carriers of paleogeographical information. Quaternary International, 72(1): 107-114.

Kaminski MA, Aksu A, Box M, Hiscott RN, Filipescu S, AlSalameen M. 2002. Late glacial to Holocene benthic foraminifera in the Marmara sea: implications for Black Sea - Mediterranean Sea connections following the last deglaciation. Marine Geology, 190(1-2): 165202.
Kaplan JO, Krumhardt KM, Zimmerman NE. 2009. The prehistoric and preindustrial deforestation of Europe. Quaternary Science Review, 28: 3016-3034.

Lambeck K, Purcell A. 2005. Sea-level change in the Mediterranean Sea since the LGM: model predictions for tectonically stable areas. Quaternary Science, $R e$ views, 24: 1969-1988.

Meisch C. 2000. Fresh water ostracoda of western and central Europe. In: Schwoerbel J, Zwick P. (eds.): Süess wasser fauna von Mitteleuropa, 1-522. Spektrum Akademischer Verlag 8/3, Heidelberg, Berlin.

Merritts DJ, Vincent KR, Wohl EE. 1994. Long river profiles, tectonism, and eustasy: A guide to interpreting fluvial terraces. Journal of Geophysical Research: Solid Earth, 99(B7): 14031-14050.

Molnar P, England P. 1990. Late Cenozoic uplift of mountain ranges and global climate change: chicken or egg? Nature, 346(6279): 29-34.

Morin E, Macaire JJ, Hinschberger F, Gay-Ovejero I, Rodrigues S, Bakyono JP, Visset L. 2011. Spatio-temporal evolution of the Choisille River (southern Parisian Basin, France) during the Weichselian and the Holocene as a record of climate trend and human activity in north-western Europe. Quaternary Science Reviews, 30(3-4): 347-363.

Morozova GS. 2005. A review of Holocene avulsions of the Tigris and Euphrates Rivers and possible effects on the evolution of civilizations in lower Mesopotamia. Geoarchaeology, 20(4): 401-423.

Morozova GS, Smith ND. 1999. Holocene avulsion history of the lower Saskatchewan fluvial system, Cumberland Marshes, Saskatchewan-Manitoba, Canada. Fluvial sedimentology 28, 231-249.

Nowacki, D., Wunderlich, J., 2012. The Lower Danube Valley through the Holocene: environmental changes and their geoarchaeological implications. In: Bebermeier W, Hebenstreit R, Kaiser E, Krause J. (eds.): Landscape Archaeology. Proceedings of the International Conference Held in Berlin, 6th - 8th June 2012. eTopoi Journal for Ancient Studies, Special Volume 3, pp. 323-329.

Nowacki D, Langan CCM, Kadereit A, Pint A, Wunderlich J. 2018. 'Lake Gorgana' - A paleolake in the Lower Danube Valley revealed using multi-proxy and regionalisation approaches. Quaternary International https://doi.org/10.1016/j.quaint.2018.09.021.

Opreanu P. 2004. Contribution to the knowledge of recent ostracod fauna from some Danube Delta lakes. Analele Universității Ovidius, Constanța, Seria Biologie Ecologie, 7: 27-32.

Owens PN, Walling DE, Leeks GJ. 1999. Use of floodplain sediment cores to investigate recent historical changes in overbank sedimentation rates and sedi- 
ment sources in the catchment of the River Ouse, Yorkshire, UK. Catena, 36(1-2): 21-47.

Panin N. 2003. The Danube delta geomorphology and Holocene evolution: a synthesis. Géomorphologie, 4: 247-262.

Panin N, Jipa D. 2002. Danube River sediment input and its interaction with the northwestern Black Sea. Estuar. Coastal Shelf Research, 54(3): 551-562.

Perşoiu I, Rădoane M. 2011. Spatial and temporal controls on historical channel responses - study of an atypical case: Someşu Mic River, Romania. Earth Surface Processes and Landforms, 36: 1391-1409.

Perșoiu I, Rădoane M, Urdea P. 2017. River behavior during Pleniglacial-Late Glacial. In: Rădoane M, Vespremeanu-Stroe A. (eds.): Landform Dynamics and Evolution. Springer, pp. 443-468.

Pillans B, Chappell J, Naish TR. 1998. A review of the Milankovitch climatic beat: template for Plio-Pleistocene sea-level changes and sequence stratigraphy. Sedimentary Geology, 122(1-4): 5-21.

Preoteasa L, Vespremeanu-Stroe A, Tătui F, Zăinescu F, Timar-Gabor A, Cîrdan I. 2016. The evolution of an asymmetric deltaic lobe (Sf. Gheorghe, Danube) in association with cyclic development of the river-mouth bar: long-term pattern and present adaptations to human-induced sediment depletion. Geomorphology, 253: 59-73.

Preoteasa L, Vespremeanu-Stroe A, Panaiotu C, Rotaru S, Țuțuianu L, Sava T, Bîrzescu I, Dimofte D, Sava G, Mirea DA, Ailincăi S. 2018. Neolithic to modern period palaeogeographic transformations in southern Danube delta and their impact on human settlements in the Enisala-Babadag region. Quaternary International, doi.org/10.1016/j.quaint.2018.09.010.

Probst JL. 1989. Hydroclimatic fluctuations of some European rivers since 1800 . Historical change of large alluvial rivers: Western Europe, 41-55.

Ramsey CB. 1995. Radiocarbon calibration and analysis of stratigraphy: the OxCal program. Radiocarbon, 37(2): 425-430.

Rădoane M, Nechita C, Chiriloaei F, Rădoane N, Popa I, Roibu C, Robu D. 2015. Late Holocene fluvial activity and correlations with dendrochronology of subfossil trunks: case studies of northeastern Romania. Geomorphology, 239: 142-159.

https:// doi.org/10.1016/j.geomorph.2015.02.036.

Rădoane M, Chiriloaei F, Sava T, Nechita C, Rădoane N, Gâza O. 2018. Holocene fluvial history of Romanian Carpathian rivers. Quaternary International, https://doi.org/10.1016/j.quaint.2018.11.014.

Ruszkiczay-Rüdiger Z, Braucher R, Novothny Á, Csillag G, Fodor L, Molnár G, \& ASTER Team. 2016. Tectonic and climatic control on terrace formation: Coupling in situ produced $10 \mathrm{Be}$ depth profiles and luminescence approach, Danube River, Hungary, Central Europe. Quaternary Science Reviews, 131: 127-147.

Sava T, Simion C, Gâza O, Stanciu I, Păceșilă D, Wacker L, Ștefan B, Moșu V, Ghiță D, Vasiliu A. 2018. Status report on the sample preparation laboratory for radiocarbon dating at the new Bucharest RoAMS center. Radiocarbon. https://doi.org/10.1017/RDC.2018.123.

Smith ND, Cross TA, Dufficy JP, Clough SR. 1989. Anatomy of an avulsion. Sedimentology, 36(1): 1-23.

Smith ND, Slingerland RL, Pérez-Arlucea M, Morozova GS, 1998. The 1870s avulsion of the Saskatchewan River. Canadian Journal of Earth Sciences, 35(4): 453-466.

Soulet G, Ménot G, Lericolais G, Bard E. 2011. A revised calendar age for the last reconnection of the Black Sea to the global ocean. Quaternary Science Reviews, 30: 1019-1026.

Stacke V, Pánek T, Sedláček J. 2014. Late Holocene evolution of the Bečva River floodplain (Outer Western Carpathians, Czech Republic). Geomorphology, 206: 440-451.

Starkel L, Ge P, Superson J. 2007. Last Glacial-Interglacial cycle in the evolution of river valleys in southern and central Poland. Quaternary Science Reviews, 26(2224): 2924-2936.

Stouthamer E, Berendsen HJA. 2001. Avulsion frequency, avulsion duration, and interavulsion period of the Holocene channel belts in the Rhine-Meuse delta, the Netherlands. Journal of Sedimentary Research, 71(4): 589-598.

Törnqvist TE. 1994. Middle and late Holocene avulsion history of the River Rhine (Rhine-Meuse delta, Netherlands). Geology, 22(8): 711-714.

Törnqvist TE, Dijk GJV. 1993. Optimizing sampling strategy for radiocarbon dating of Holocene fluvial systems in a vertically aggrading setting. Boreas, 22(2): 129-145.

Turner F, Tolksdorf JF, Viehberg F, Schwalb A, Kaiser K, Bittmann F, ... \& Veil S. 2013. Lateglacial/early Holocene fluvial reactions of the Jeetzel river (Elbe valley, northern Germany) to abrupt climatic and environmental changes. Quaternary Science Reviews, 60: 91109.

Van Dinter M, Coehn KM, Hoek WZ, Stouthamer EJ, Middelkoop H. 2017. Late Holocene lowland fluvial archives and geoarchaeology: Utrecht's case study of Rhine river abandonment under Roman and Medieval settlement. Quaternary Science Reviews, 1-39.

Vespremeanu-Stroe A, Preoteasa L, Hanganu D, Brown T, Bîrzescu I, Toms P, Timar-Gabor A. 2013. The impact of the Late Holocene coastal changes on the rise and decay of the ancient city of Historia (Southern Danube Delta). Quaternary International, 293: 245-256. 
Vespremeanu-Stroe A, Preoteasa L, Zăinescu F, Rotaru S, Croitoru L, Timar-Gabor A. 2016. Formation of Danube delta beach ridge plains and signatures in morphology. Quaternary International, 415: 268-285.

Vespremeanu-Stroe A, Zăinescu F, Preoteasa L, Tătui F, Rotaru S, Morhange C, Stoica M, Hanganu J, TimarGabor A, Cârdan I, Piotrowska N. 2017a. Holocene evolution of the Danube delta: an integral reconstruction and a revised chronology. Marine Geology, 388: $38-61$.

Vespremeanu-Stroe A, Preoteasa L, Zăinescu F, Tătui F. 2017b. The evolution of Danube delta after Black Sea reconnection to World Ocean. In: Rădoane $\mathrm{M}$, Ves-
premeanu-Stroe A. (eds.): Landform dynamics and evolution in Romania, Springer, pp. 521-549.

Wang Q, Li Y, Wang Y. 2011. Optimizing the weight losson-ignition methodology to quantify organic and carbonate carbon of sediments from diverse sources. Environmental Monitoring and Assessment, 174(1-4): 241-257.

Wilkinson SN, Dougall C, Kinsey-Henderson AE, Searle RD, Ellis RJ, Bartley R. 2014. Development of a timestepping sediment budget model for assessing land use impacts in large river basins. Science of the Total Environment, 468: 1210-1224. 